\title{
An Approach to Co-Design and Self-Regulated Learning in Technological Environments. Systematic Review
}

\author{
Sofía Villatoro Moral $(1)$ and Barbara de Benito () \\ Department of Applied Pedagogy and Educational Psychology, University of the Balearic Islands (UIB), Spain
}

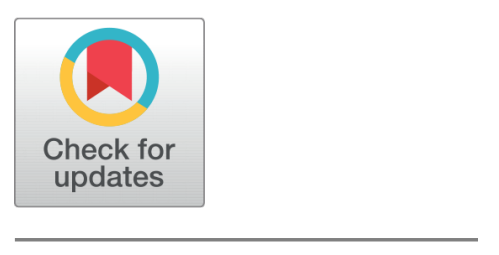

Received 2020-08-23

Revised 2020-10-02

Accepted 2021-01-20

Published 2021-07-15

Corresponding Author

Sofía Villatoro Moral,

sofia.villatoro@uib.es

Carretera de Valldemossa, km 7.5, 07122 Palma, Illes Balears, Spain.

DOI https://doi.org/10.7821/ naer.2021.7.646

Pages: 234-250

Funding: Ministry of Science, Innovation and Universities, Spain

(Award:EDU2017-84223-R)

Distributed under

Creative Commons CC BY 4.0

Copyright: (C) The Author(s)

\section{OPEN ACCESS}

\section{ABSTRACT}

Present-day society calls for new student-centred didactic methodologies that make the student an active participant in their learning process. Strategies aimed at training citizens and professionals must adapt and respond to a society that is constantly changing. In this context, self-regulated learning and educational co-design emerge as key concepts in the development of new educational approaches. The present study seeks to identify the elements shared by models of self-regulation and educational co-design in technology-enhanced learning environments. To this end, a systematic review of the scientific literature during the period 2014-2019 has been conducted. The search was carried out using five databases: (1) Ebsco Host; (2) Web of Science; (3) Scopus; (4) ERIC; (5) Dialnet. A total of 830 references and 21 papers meeting the criteria for inclusion were identified. An analysis of the studies selected enabled us to identify the self-regulation models associated with co-design learning processes, as well as the elements they have in common. These include planning, motivation, cognition, task management, collaboration, and degree of success. The results provide the first steps for the construction of a co-design model, which includes guidelines for the creation of personalised learning pathways in technology-enhanced environments.

Keywords SELF-REGULATION OF LEARNING, LEARNING ENVIRONMENTS, ICT, INSTRUCTIONAL DESIGN, STUDENT PARTICIPATION

\section{INTRODUCTION}

Learning processes demand new strategies to engage with students and their educational needs. Research in this field has been increasing. Recent studies in higher education suggest that the knowledge people need to live, work, and to become competitive professionals in society is interdisciplinary and problem-oriented (Freeman, Becker, Cummins, \& Davis, 2017). Similarly, the OECD Skills Outlook 2019 (2019) points to the importance of using technology as a way of acquiring skills for the 21 st century. At the same time, it reiterates the value of tools that help students to personalise and regulate their own learning. This 
implies the creation of educational environments that offer solutions to the issues raised by the digital era and the educational community, focusing on aspects that include the learners themselves, their learning processes, and course content (Roschelle, Penuel, \& Shechtman, 2006). Based on this perspective, several teaching methodologies and approaches have been developed that stress the importance of the teacher-student relationship as a key factor in educational co-design practices (Bovill, 2020; Kinzie \& Kuh, 2017; Kuh, 2008; Magolda \& Astin, 1993). Whenever student-centred design is implemented, it is important that the students are the protagonists (Gros, 2019). Thus, the application of co-design techniques to foster participation, collaboration and co-creation between teachers and students at classroom level is essential (Bovill, 2020).

\subsection{Co-Designing Learning}

The term co-design is a complex one to define, as it draws on a range of perspectives. It refers to the collective creativity of knowledge, to the advancement of the implementation of technological designs that respond to educational needs (Gros, 2019) and to learning processes (Hannon, Danahi, Schneider, Coopey, \& Garber, 2012; Leinonen \& Durall-Gazulla, 2014; Penuel, 2019; Zheng, 2015). Co-design procedures are linked to participatory and collaborative research methods (Bovill, 2020; Gros, 2019). Their origins lie in the Scandinavian tradition, associated with instructional design, constructivist principles and connectivist theories (Mor \& Craft, 2012). For this reason, Kalantzis and Cope (2010) argue that codesign-based strategies represent a shift in instructional practices, in the roles played by participants, and in student decision-making with respect to content. Currently, studies using this methodology are based on the production of learning materials, curriculum development, the creation of a product, or as a training system (Janssen, Könings, \& van Merriënboer, 2017; Könings, Seidel, \& Merriënboer, 2014; Penuel, 2019). Likewise, Roschelle, et al. (2006, p. 607) state that for co-design to take place, a number of criteria must be met. It needs to: (1) Involve concrete, tangible innovation; (2) Be developed through design-based research, participatory research or formative research; (3) Be flexible and potentially have different iterations; (4) Be the result of a participatory teamwork experience; (5) Respect learning cycles; (6) Include virtual or face-to-face actions to facilitate teamwork; (7) Require the participants in the process to assume responsibility; (8) Use complex data analysis and allow for the introduction of interdisciplinary methods, thus enhancing validity and objectivity.

From an educational point of view, co-design initiatives happen when teachers and students work together collaboratively to create course components and/or pedagogical approaches (Bovill, Cook-Sather, Felten, Millard, \& Moore-Cherry, 2016). From a practical point of view, there is no single way of delivering co-design. Different methods and tools exist, although there are similarities between them (Mor, Ferguson, \& Wasson, 2015; Pastor, Lozano, \& Gros, 2017). In light of these considerations, recent studies show that this type of participation can promote deeper learning among students, as well as provide key insights to guide teacher intervention (Gros, 2019). 


\subsection{Self-Regulation of Learning}

Zimmerman's work (1989) in this field was groundbreaking. His studies describe selfregulated students as those who are in control of their own learning processes, based on metacognitive, motivational and behavioural variables. At the same time, Mccombs (1989) emphasised the active role of students in selecting their own goals, planning strategies and evaluating their own learning performance. Consequently, there are different theoretical models that define self-regulated learning from different perspectives, and among these we should highlight the following:

- Zimmerman's cyclical model, Zimmerman (2000) and Zimmerman and Moylan (2009). Self-regulation is organised around three stages: forethought, performance and self-reflection.

- Bandura $(1986,1997)$ and Zimmerman $(1989,2008)$. Self-regulated learning is a socially driven process, one in which the student sets her or his learning objectives, monitoring, regulating and controlling the acquisition of knowledge, being guided by goals and context.

- Boekaerts' Heuristic Model (1995; 1996). This model articulates psychological aspects, including motivation, emotion, metacognition, self-concept and learning. Here, importance is placed on task evaluation by the learner.

- Winne and Hadwin's four-stage model (Winne \& Hadwin, 2008). It focuses on the way students' cognitive processing works when planning, developing and evaluating a task.

- The Pintrich model (2000). This is a four-stage model for achieving self-regulation: forethought, monitoring, control and reflection.

Co-design procedures are closely related to self-regulation, in terms of flexibility and the pace of learning. According to Zimmerman (2001), the main cause of student failure is an inability to self-regulate effectively. This assertion is in line with what was recently put forward by the OECD Skills Outlook 2019 (2019). For years now, various approaches have been taken towards the exploration of student participation in curriculum planning and design. The aim has been to incorporate student views on teaching, and to achieve improvements in a collaborative way (Bain \& Zimmerman, 2009).

\subsection{Technological Learning Contexts}

Technology Enhanced Learning Environments (TELE) refers to contexts that facilitate the acquisition of knowledge and skills with the support of ICT (Steffens et al., 2015). With regard to technology, it is important to distinguish between course-specific resources and applications for group work. In this sense, it is necessary to consider which technological tools can be adapted to the characteristics of these methodologies and to student needs (Gros, 2019). Currently there are few studies that address the issue of technological applications used in co-design processes. Research is needed in this area to analyse what kind of tools can improve teaching-learning processes. However, more evidence has been found 
regarding technologies that favour self-regulation, showing that digital technologies have great potential for the development of self-regulation (Marcelo \& Rijo, 2019).

Accordingly, the aim of this study was to identify models of self-regulated learning associated with educational co-design in technology-enhanced learning environments. Through a systematic review of the literature, we aim to answer the following questions: Which models of self-regulation are associated with the co-design of learning in TELE?

Which models of co-design are associated with the self-regulation of learning in TELE? How are the relationships between the different agents involved in co-design in TELE established? What kind of technology is used to support the co-design and self-regulation processes?

\section{METHODS}

Systematic reviews seek to draw together all the knowledge in a specific area, highlighting what is known about a particular topic through the results obtained in different studies, and to provide recommendations regarding future research and practice (Moreno, Muñoz, Cuellar, Domancic, \& Villanueva, 2018). As a first step, it is necessary to establish criteria to determine which articles are to be selected as part of the final sample, and which are not. To this end, the principles set out in the PRISMA declaration (Urrútia \& Bonfill, 2010) were taken into account. The review process was performed in four stages:

Stage 1. Localisation of the articles. At this stage search criteria were established, and databases chosen: 830 scientific articles in English and Spanish, published between 20142019 were identified on the following databases: (1) Ebsco Host; (2) Web of Science; (3) Scopus; (4) ERIC; (5) Dialnet. Being aware that the terminology used to define this concept is extremely diverse, we chose to locate articles that specifically use the terms co-design, self-regulation and technology, thus configuring the following search string: Co-design OR codesign OR co design AND learning AND techno* OR computer AND self-regulation OR self regulation.

Stage 2. Selection and eligibility. The purpose and the context of the research conditions determined the inclusion and exclusion criteria, as shown in Table 1. In order to apply these criteria, records from the databases were imported into the Rayyan QCRI tool, which allows the criteria to be applied collaboratively (Aveyard, 2007). Duplicates were eliminated, and an initial analysis was carried out using the abstracts of the articles. Those that did not meet the inclusion criteria were excluded, which left 197 articles for the next stage.

Stage 3. Analysis of the selected articles. A protocol was developed for the purpose of extracting specific information and establishing a classification system using the Airtable database. The items included in the protocol were: (1) Years; (2) Authors; (3) Title of article; (4) Self-regulation model; (5) Elements; (6) Co-design model; (7) Co-design elements; (8) Agents involved in co-design; (9) Technology; (10) Attached article; (11) Remarks. Once all articles had been analysed, those that did not meet the inclusion criteria were excluded.

Stage 4. Analysis of the articles included. The protocol was applied to the 21 articles selected in order to carry out an in-depth analysis and to extract the relevant information. 
Table 1 Inclusion and exclusion criteria

Inclusion criteria

Years published: 2014-2019

They involve the use of technology

Refers to joint co-design actions in learning processes

Refer to self-regulatory processes within teaching

The work is focused on the educational field, specifically the learning teaching processesTipo de publicación: Artículo

Type of publication: ArticleTipo de publicación: Artículo

\section{Exclusion criteria}

Year of publication different from the period from 2014-2019

The theme not related to co-design and self-regulation

No use is made of technology

The term self-regulation is applied in areas other than teaching.

Documents belong to areas other than educational.Tipo de publicación: Artículo

Type of publication. Reviews, meta-analysis and doctoral thesesRevisiones y metaanálisis

Figure 1 shows the review process described in the previous section, following the criteria set out in the PRISMA declaration (Urrútia \& Bonfill, 2010).

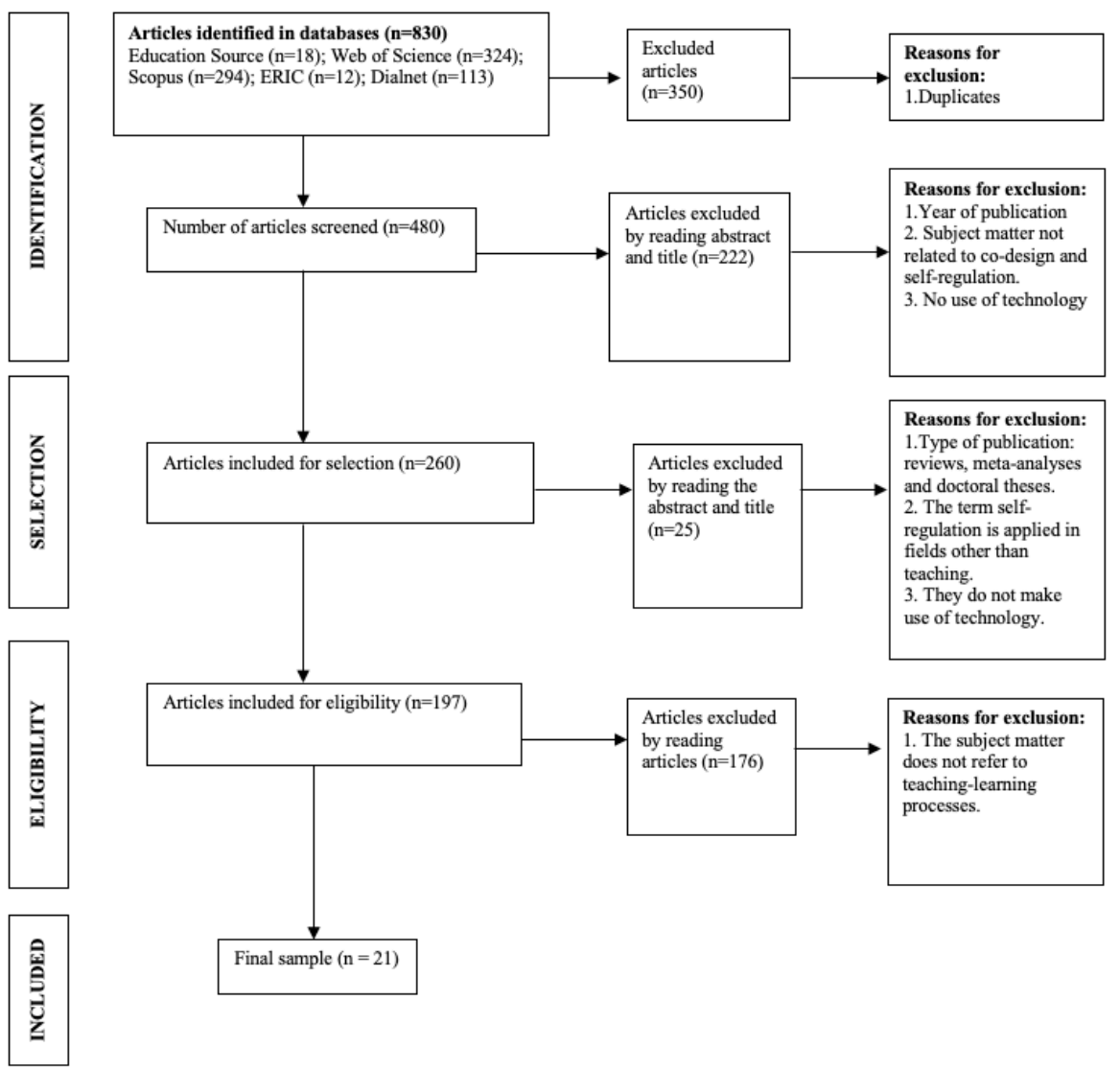

Figure 1 Adaptation of the PRISMA flowchart (Hutton, Catalá-López, \& Moher, 2016) showing the different stages involved in this systematic review. 
The 21 manuscripts representing the sample selected are presented in chronological order in the form of a table (Table 2). The search took place in December, and some publications from the year 2020 were finally included.

\begin{tabular}{lll}
\hline \multicolumn{1}{l}{ Table 2 Papers analyzed in the systematic review } & \\
Article analyzed & Reference & Type \\
\hline 1 & Cortada-Pujol et al. (2014) & Article \\
2 & Criko et al. (2015) & Article \\
3 & Manso and Llamas (2015) & Article \\
4 & Järvelä (2015) & Article \\
5 & Littlejohn and Milligan (2015) & Article \\
6 & Weitze (2015) & Congress \\
7 & Bovill et al. (2016) & Article \\
8 & González et al. (2016) & Article \\
9 & Zhao (2016) & Article \\
10 & Barbera et al. (2017) & Article \\
11 & Kintu et al. (2017) & Article \\
12 & Zahedi and Heaton (2017) & Article \\
13 & Trischler et al. (2018) & Article \\
14 & Celuch et al. (2018) & Article \\
15 & Garcia et al. (2018) & Article \\
16 & Hyysalo et al. (2019) & Article \\
17 & González-Yebra et al. (2019) & Article \\
18 & Wareing et al. (2019) & Article \\
19 & Higgins et al. (2019) & Article \\
21 & Bovill (2020) & Article \\
\hline & Dural et al. (2020) & Article \\
\hline
\end{tabular}

\section{RESULTS}

This section presents the results in relation to the research questions posed.

\subsection{Self-Regulation Models Associated with the Learning Co-Design Process}

The concepts underpinning self-regulation models appear in the theoretical frameworks or in the conclusions of the research analysed. In a single paper, reference is made to one or sometimes to several models of self-regulation. Thus, there are others that mention the contributions made by Zimmerman, although they do not cite a specific model. Moreover, the term self-regulation appears without being linked to any theoretical approach (Figure 2).

Each theoretical contribution proposes certain stages for the achievement of selfregulation, in which a series of elements appear. These are detailed in the papers. The processes and elements of the self-regulation models found in the papers analysed are specified below (Table 3): 


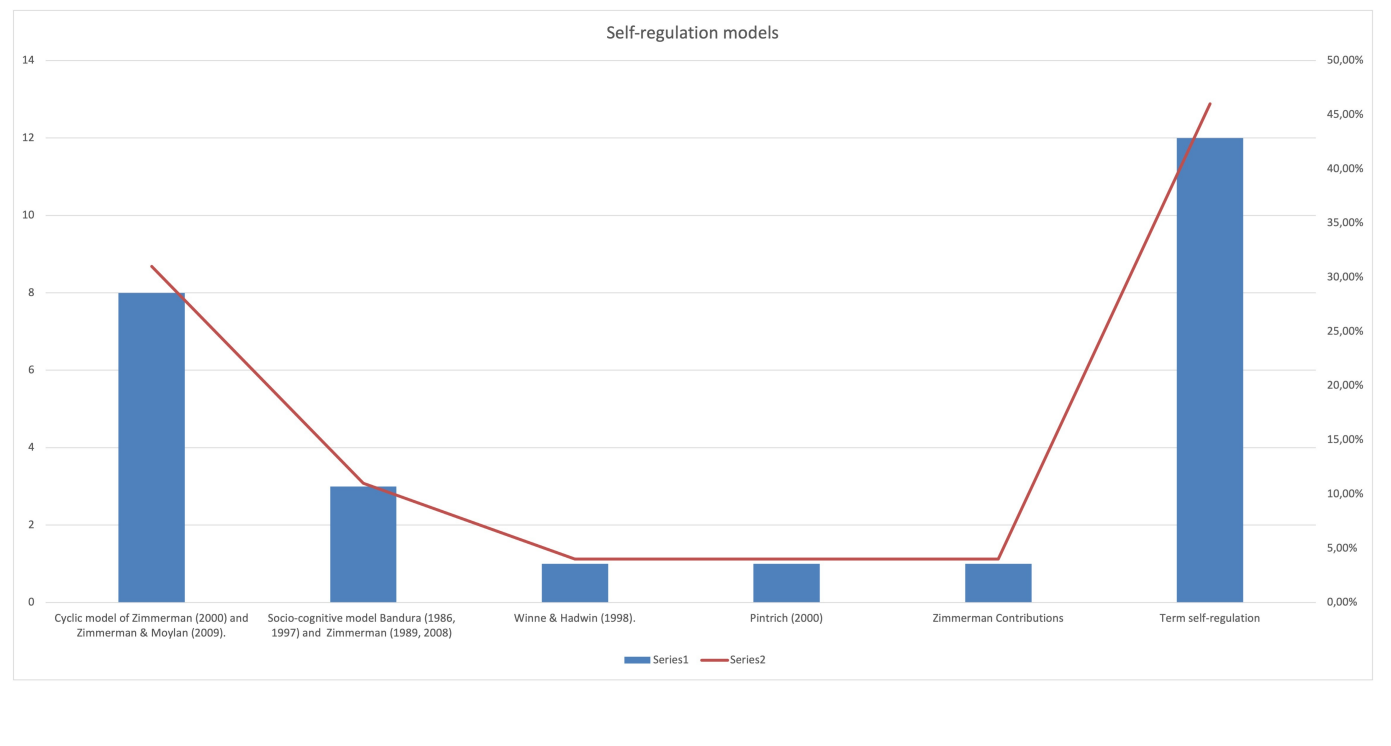

Figure 2 Self-regulation models associated with the co-design of learning process.

The key elements that appear repeatedly in the processes of self-regulation are: Planning $(n=17)$; Motivation $(n=8)$; Organisation $(n=6)$; Evaluation $(n=5)$; Task execution $(n=4)$; Goals $(n=3)$; Cognition $(n=3)$; Learning strategies $(n=2)$. Other factors are mentioned once only. Planning stands out ahead of the rest $(n=17)$. The term is to be understood from the point of view of organisation at the individual level. In other words, the self-regulation process begins with an analysis of the task, broken down into smaller units. Subsequently goals are set, and a personal strategy for how they are to be achieved is established, using prior knowledge as a starting point (Panadero \& Alonso-Tapia, 2014; Zimmerman \& Moylan, 2009). Furthermore, according to Zimmerman (2008), planning is the self-regulatory process par excellence, as it determines student success. Motivation $(n=8)$ comes in second place, as a crucial concept for task planning and development (Panadero \& Alonso-Tapia, 2014).

\subsection{Co-Design Models Associated with the Self-Regulation of the Learning Process}

The conceptualisations of co-design analysed refer to a collaborative process of course/curriculum design. The actions developed and the nature of the relationship between their components are what characterise each perspective. The co-design models presented in the papers reviewed and the concepts that underpin them are specified in Table 4:

The model that appears most frequently is collaborative $(n=9)$, followed by participatory $(n=5)$ and service-learning based co-design $(n=3)$. Occasionally, collaborative and participatory models are mentioned in the same research project. Consequently, some authors consider that a rewarding design process needs to include both. In a similar vein, some research points to differences in this respect, specifically in terms of the degree of participant involvement. This implies that sometimes collaborative processes do not involve the 
Table 3 Self-regulation models, processes and key elements

\begin{tabular}{|c|c|c|}
\hline Reference models & Learning Self-Regulation Process & Elements \\
\hline Cyclic model of Zimmerman (2000) and Zimmerman and Moylan (2009) & Planning Reflection Execution & $\begin{array}{l}\text { Motivation } \\
\text { Self-observation } \\
\text { Self control } \\
\text { Time management } \\
\text { Success } \\
\text { Self appraisal } \\
\text { Evaluation } \\
\text { Beliefs } \\
\text { Forecast } \\
\text { Attention } \\
\text { Reflection } \\
\text { Planning" }\end{array}$ \\
\hline Pintrich (2000) & $\begin{array}{l}\text { Preparation, planning and activa- } \\
\text { tion } \\
\text { Monitoring } \\
\text { Control } \\
\text { Process evaluation }\end{array}$ & $\begin{array}{l}\text { Motivation } \\
\text { Cognition } \\
\text { Success } \\
\text { Time management } \\
\text { Evaluation }\end{array}$ \\
\hline Winne and Hadwin (1998) & $\begin{array}{l}\text { Defining tasks } \\
\text { Definition of goals and plans } \\
\text { Implementation of tactics } \\
\text { Metacognition adaptation }\end{array}$ & $\begin{array}{l}\text { Success } \\
\text { Goals } \\
\text { Planning } \\
\text { Cognition } \\
\text { Evaluation }\end{array}$ \\
\hline Socio-cognitive model Bandura $(1986,1997)$ and Zimmerman $(1989,2008)$ & $\begin{array}{l}\text { Process planning } \\
\text { Definition of the objectives } \\
\text { Organization of information } \\
\text { Supervision }\end{array}$ & $\begin{array}{l}\text { Self-efficacy } \\
\text { Motivation } \\
\text { Success } \\
\text { Self control } \\
\text { Expectations } \\
\text { Attention } \\
\text { Beliefs } \\
\text { Organization } \\
\text { Planning } \\
\text { Interests objectives } \\
\text { Supervision }\end{array}$ \\
\hline
\end{tabular}

introduction and discussion of participants' ideas. Actions are reduced to carrying out the assigned task.

However, for participatory design to take place, it is necessary for individuals to actively participate by expressing their opinions and providing input, thus enabling interaction with the group. Studies show a number of elements that appear in the co-design process, which are detailed in Table 5. The most common are collaboration $(n=16)$, motivation $(n=10)$, participation $(n=9)$, planning $(n=8)$ and goal setting $(n=7)$. Other items are mentioned between $(n=5)$ and $(n=1)$ in the documents analysed (Table 5).

\subsection{Relationships Between the Different Agents Involved in Co-Design}

The partnerships through which co-design actions take place vary depending on the project. Four types of interactions have been observed in the studies reviewed: 
Table 4 Co-design models associated with self-regulation

\section{Co-design model}

Co-design based on participatory design

Co-design based on intermediate design

Student voice based co-design

Service-learning based co-design

Co-design SAP (Students as Partners)

Co-design based on the Kano approach

Co-design based on the Collaborative Model

Inquiry-based co-design

\section{Definition}

It aims at collaboration between participants (Bovill, 2020).

It describes how the teacher shapes social processes and creates conditions for learning, as well as the phenomenon of the individual learner constantly recreating or redesigning information through his or her own meaning-making processes. It refers to the design of small things to form a larger design.

According to Anderson and Shattuck (2012) it is a methodology that has the main characteristic of developing multiple collaborative interactions for the purpose of evaluating, innovating and improving teaching and learning processes. The participation of students requires planning and implementation, to ensure that the final design truly responds to their needs and interests.

Learning design is based on the needs, experience and service to the community targeted by the project to be designed (Yu \& Sangiorgi, 2018).

It is a model that involves students and staff (including academic/teaching and professional staff) working together in teaching and learning in higher education. Partnership is a reciprocal process through which all participants have the opportunity to contribute equally, to curricular or pedagogical conceptualisation, decisionmaking, implementation, research or analysis (Bovill et al., 2016)

The model provides a better understanding of how customers evaluate a product or its offering and helps companies identify those attributes that need to be improved (Rotar \& Kozar, 2017).

Students work cooperatively within a project, their learning experience is enriched: they better understand the complexity of the design project.

It is based on questions and the scientific process so that students gain personal experience with scientific enquiry: identifying and asking questions, designing and conducting investigations, analysing evidence, using models and explanations, and communicating results (Abdelraheem \& Asan, 2006).

\begin{tabular}{ll}
$\boldsymbol{f}$ & $\mathbf{\%}$ \\
\hline 5 & $23 \%$ \\
1 & $4 \%$
\end{tabular}

1

Table 5 Elements related to co-design and self-regulation

\begin{tabular}{llllllll} 
Co-design elements & $\boldsymbol{f}$ & Co-design elements & $\boldsymbol{f}$ & Co-design elements & $\boldsymbol{f}$ & Co-design elements & $\boldsymbol{f}$ \\
\hline Collaboration & 16 & Evaluation & 3 & Stimulation & 1 & Responsibility & 1 \\
Motivation & 10 & Feed-back & 3 & Time planning & 1 & Dialogue & 1 \\
Participation & 9 & Organization & 3 & Regulation & 1 & Co-creation & 1 \\
Planning & 8 & Teamwork & 3 & Task execution & 1 & Reflection & 1 \\
Objectives & 7 & Communication & 3 & Affective aspects of content & 1 & Structure & 1 \\
Needs & 5 & Interaction & 2 & Rules & 1 & & \\
Goals & 5 & Learning strategies & 2 & Instructions & 1 & & \\
Success & 4 & Adaptability & 2 & Learning attitudes & 1 & \\
Cognition & 4 & Expectations & 1 & Support & 1 & \\
\hline
\end{tabular}

- Between pupils. Takes place when a group of students carry out a task or work on a project together.

- Between teachers. This implies the participation of all teaching staff in working on tasks or projects with the aim of developing them with the students.

- Teachers and pupils. The interaction between the two groups involves taking decisions on the teaching processes to be followed during a class, an activity or a course. 
- Teachers and other professionals. At this level, co-design is achieved by means of contributions from both teachers and external experts on a given subject. Their collaboration generates projects, activities and outcomes for implementation in the classroom.

In the records analysed, level one interactions occurred in $38 \%(n=8)$. At level two, interaction between teachers $(n=7) 33 \%$. At level three, between pupils and teachers $(n=4) 19 \%$. And at level four, between teachers and external experts $(n=2) 10 \%$.

\subsection{Technology Used to Support the Co-Design and Self-Regulation Processes}

The research specifies the use of virtual learning environments to develop co-design and self-regulation actions. Institutional platforms, 3D virtual environments or MOOCs are used. The tools are linked to Zimmerman (2000) and Zimmerman and Moylan (2009) cyclical model of self-regulation, as this is the one most frequently referred to. Thus, each is linked to the stages within this model, and in turn to the co-design models used. The applications used fulfil a series of functions based on the processes of communication, planning and/or organisation, task execution and reflection (Table 6).

\begin{tabular}{|c|c|c|c|}
\hline Technology & $f$ & Tools & Functions \\
\hline \multirow[t]{15}{*}{ Institutional platform } & 7 & Infographic & Planning the learning teaching process \\
\hline & & Calendar & Organization and management \\
\hline & & WebQuests & Organization and management. Task execution \\
\hline & & Message forum & $\begin{array}{l}\text { Reflection and creation of documents. Com- } \\
\text { munication }\end{array}$ \\
\hline & & Concept map & Organization and management \\
\hline & & Storyboard & Organization and management \\
\hline & & Videos & Reflection \\
\hline & & Wiki & $\begin{array}{l}\text { Reflection and creation of documents. Com- } \\
\text { munication }\end{array}$ \\
\hline & & Social bookmarks & Task execution \\
\hline & & Computer-supported collaborative learning (CSCL) & Task execution and reflection \\
\hline & & Learning management system (LMS) & Task execution and reflection \\
\hline & & Internet browser & Task execution \\
\hline & & Google Docs & Task execution and reflection \\
\hline & & Questionnaire & Reflection and evaluation \\
\hline & & Email & Communication \\
\hline \multirow[t]{2}{*}{ MOOCS } & 1 & Calendar & Organization and management \\
\hline & & Chat & Organization and management \\
\hline Virtual games & 1 & Infographic & Planning the learning teaching process \\
\hline
\end{tabular}




\section{DISCUSSION AND CONCLUSIONS}

On the basis of the review carried out, the publications that address co-design and selfregulation within technological environments are scarce $(n=21)$, which shows that the central focus of these studies is not technology, indicating the need to develop research in this field as pointed out by Gros (2019) , although the subject is beginning to be of interest. On the other hand, one of the objectives was to understand the self-regulation models that are usually associated with educational co-design. In this regard, the results indicate that only 8 cases are linked with a specific model, and that in most cases self-regulation is addressed without an approach having been chosen in advance. The perspectives related to co-design were participatory and collaborative models. These emphasise the importance of participation between students and teachers so that deeper learning can take place (Bovill, 2020). Projects have been co-designed by means of workshops or participatory activities, led and coordinated by teachers or researchers. The conclusions drawn from these kinds of experiences are intended to construct new knowledge that will facilitate dissemination and transfer in order to develop innovative designs. However, Gros (2019) warns that there are limitations to the publication of this type of research in scientific journals. The different studies analysed show that there can be different interactions and levels of co-design, depending on the degree of involvement of all the participants in the process. The following diagram shows the different interactions (Figure 3).

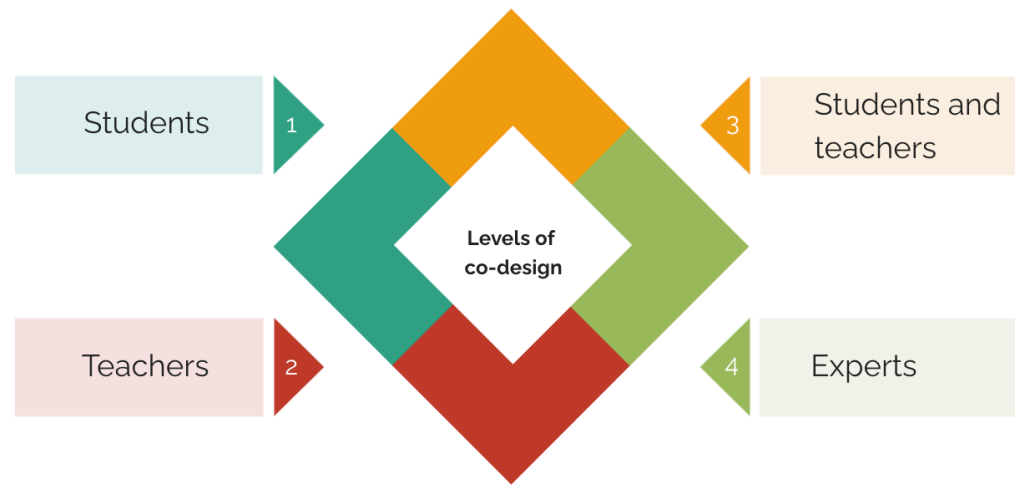

Figure 3 Levels in the co-design of learning.

An analysis of the concepts related to the self-regulation of learning and co-design shows $\mathrm{n}=12$ commonalities between the elements of each variable. At the same time, synchrony is identified between the most frequently reiterated items in the self-regulation and co-design models. Planning and motivation top the number of commonalities (Figure 4).

The acquisition of knowledge by the student is linked to participation, design, planning and motivation. In this case technology provides tools that support the process, although there are no specific studies on this (Gros, 2019). Planning and cognition are directly linked to Zimmerman (2000) cyclical self-regulation model and its subsequent revision by Zimmerman and Moylan (2009). Planning is the quintessential self-regulatory process and is a 


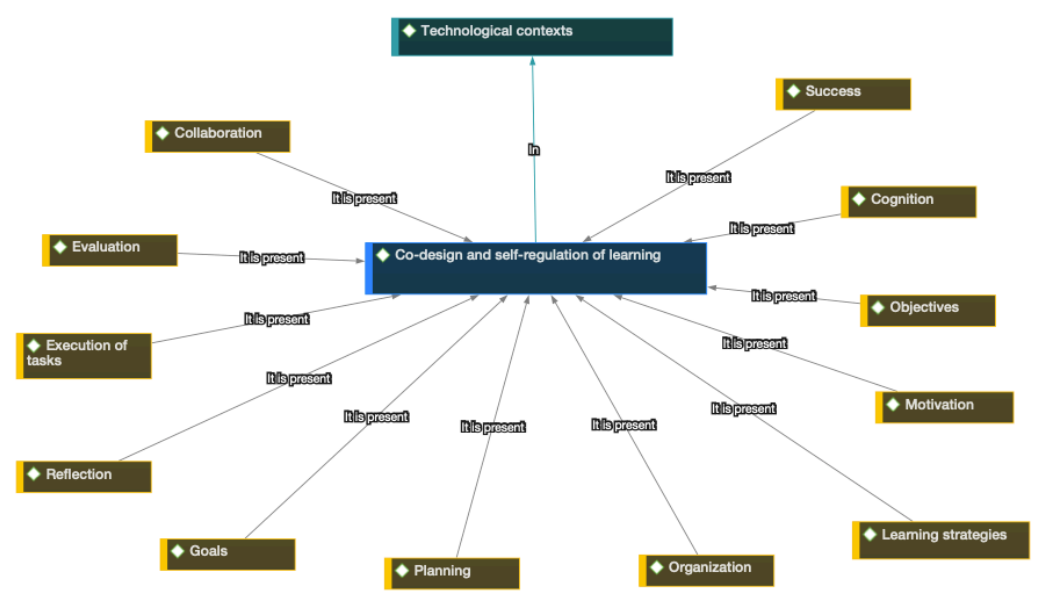

Figure 4 Common elements in the co-design and self-regulation models.

predictor of task success. That is, the more time spent planning, the better the results (Zimmerman, 2008). Self-assessment is the student's evaluation of the validity of their own work. This is based on established criteria, and the achievement standard that has been set for the activity ?. These factors are also closely related to co-design, as if they are established beforehand, this will change the learner's perception of the task. Consequently, planning and motivation are linked to the learner's perception of his or her own learning in technological environments, and of the tasks to be performed.

The technological environments in which co-design-based projects are developed do not make reference to the concrete specifications of a model to be followed. But technology is emphasised as a support for graphic and visual representations, planning, the development of individual and/or collaborative tasks, and as a means of group communication. The research does not recommend or feature specific technological tools for developing codesign models. Instead, a combination of common tools is used in the stages of co-design, which are in turn linked to self-regulation models.

The results obtained through systematic review have enabled us to come up with the first draft of a co-design model that favours the process of self-regulation in technologyenhanced environments. Figure 5 shows sample size characterised by: level of co-design determined by interaction between the agents participating in the educational process (teacher-student-expert or other professionals); the roles and social relations inherent to participatory design; the stages within the self-regulation of learning based on Zimmerman (2000) and Zimmerman and Moylan (2009) cyclical model; and the technology used to support the whole process. 


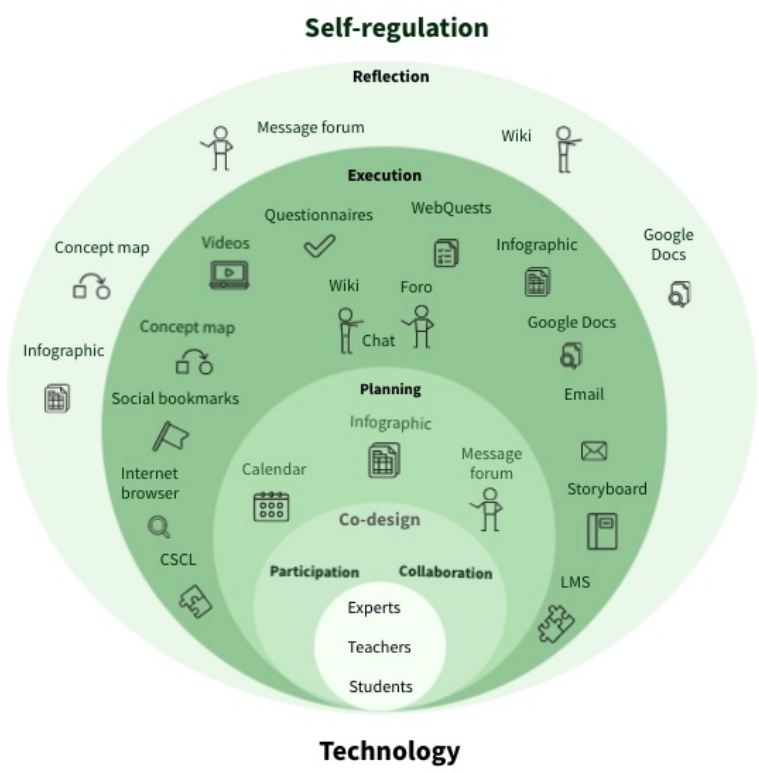

Figure 5 Tools related with self-regulation processes in the co-design of learning

\section{ACKNOWLEDGEMENTS}

Funded by: Ministry of Science, Innovation and Universities, Spain

Funder Identifier: http://dx.doi.org/10.13039/100014440

Award: EDU2017-84223-R

\section{ADDITIONAL INFORMATION AND DECLARATIONS}

The authors declare that they have no potential conflict of interest with respect to the research, authorship, and/or publication of this article.

\section{REFERENCES}

Abdelraheem, A., \& Asan, A. (2006). The Effectiveness of Inquiry-Based Technology Enhanced Collaborative Learning Environment. Int. J. Technol Teach Learn, 2.

Anderson, T., \& Shattuck, J. (2012). Design-Based Research: A Decade of Progress in Education Research? Educational Researcher, 41(1), 16-25. https://doi.org/10.3102/0013189X11428813

Bain, K., \& Zimmerman, J. (2009). Understanding Great Teaching. Peer Review, 11(2).

Bandura, A. (1986). Social foundations of thought and action: A social cognitive theory. Englewood Cliffs, NJ: Prentice-Hall.

Bandura, A. (1997). Albert Bandura and the Exercise of Self-Efficacy. Journal of Cognitive Therapy, 13(2).

Barbera, E., Garcia, I., \& Fuertes-Alpiste, M. (2017). A Co-Design Process Microanalysis: Stages and Facilitators of an Inquiry-Based and Technology-Enhanced Learning Scenario. The International Review of Research in Open and Distributed Learning, 18. https://doi.org/10.19173/ irrodl.v18i6.2805 
Boekaerts, M. (1995). Self-regulated learning: Bridging the gap between metacognitive and metamotivation theories. Educational Psychologist, 30(4), 195-200. https://doi.org/10.1207/ s15326985ep3004_4

Boekaerts, M. (1996). Self-regulated Learning at the Junction of Cognition and Motivation. European Psychologist, 1(2), 100-112. https://doi.org/10.1027/1016-9040.1.2.100

Bovill, C. (2020). Co-creation in learning and teaching: the case for a whole-class approach in higher education. Higher Education, 79(6), 1023-1037. https://doi.org/10.1007/s10734-019-00453 $-\mathrm{W}$

Bovill, C., Cook-Sather, A., Felten, P., Millard, L., \& Moore-Cherry, N. (2016). Addressing potential challenges in co-creating learning and teaching: overcoming resistance, navigating institutional norms and ensuring inclusivity in student-staff partnerships. Higher Education, 71(2), 195-208. https://doi.org/10.1007/s10734-015-9896-4

Celuch, K., Bacic, D., Chen, M., Maier-Lytle, J., \& Smothers, J. (2018). The Potential of Student CoCreation in Extracurricular Experiences. Marketing Education Review, 3, 230-243. https:// doi.org/10.1080/10528008.2017.1419432

Cortada-Pujol, M., López, M., Marimon, M., Gros, B., Creus, A., Estruch, A., ... Pastor, X. (2014). Diseño de escenarios de aprendizaje basados en la indagación con soporte tecnológico. Estrategias de co-diseño entre docentes e investigadores. Revista del CIDUI, 2. Retrieved from https://www.cidui.org/revistacidui/index.php/cidui/article/view/506

Cviko, A., McKenney, S., \& Voogt, J. (2015). Teachers as co-designers of technology-rich learning activities for early literacy. Technology, Pedagogy and Education, 24(4), 443-459. https:// doi.org/10.1080/1475939x.2014.953197

Dural, E., Bauters, M., Hietala, I., Leinonen, T., \& Kapros, E. (2020). Co-creation and co-design in technology enhanced learning: Innovating science learning outside the classroom. . Interaction Design and Architecture(S), 42, 202-226. Retrieved from https://url2.cl/Tf517

Freeman, A., Becker, S., Cummins, M., \& Davis, A. (2017). Resumen Informe Horizon. Educación Primaria y Secundaria, 2017, 0-23.

Garcia, I., Noguera, I., \& Cortada-Pujol, M. (2018). Students' perspective on participation in a codesign process of learning scenarios. The Journal of Educational Innovation, Partnership and Change, 4(1). https://doi.org/10.21100/jeipc.v4i1.760

González, A., Escofet, A., Obiols, N., \& Masgrau, M. (2016). Learning service and codesign in teacher training: integration ways of students' experiences and perspectives. Bordón. Revista de Pedagogía, 68(2), 169-169. https://doi.org/10.13042/bordon.2016.68211

González-Yebra, O., Aguilar, M. A., Aguilar, F., \& Lucas, M. (2019). Co-Design of a 3D Virtual Campus for Synchronous Distance Teaching Based on Student Satisfaction: Experience at the University of Almería (Spain). Education Sciences, 9. https://doi.org/10.3390/educsci9010021

Gros, B. (2019). La investigación sobre el diseño participativo de entornos digitales de aprendizaje. Retrieved from https://url2.cl/WA2bv

Hannon, D., Danahi, E., Schneider, L., Coopey, E., \& Garber, G. (2012). Encouraging teachers to adopt Inquiry bades learning by engaging in participatory design. Integrated STEM Education Conference (ISEC) 2012 IEEE 2nd (Vol. 9). https://doi.org/10.1109/ISECon.2012.6204169

Higgins, D., Dennis, A., Stoddard, A., Maier, A. G., \& Howitt, S. (2019). 'Power to empower': conceptions of teaching and learning in a pedagogical co-design partnership. Higher Education Research \& Development, 38, 1154-1167. https://doi.org/10.1080/07294360.2019.1621270

Hutton, B., Catalá-López, F., \& Moher, D. (2016). La extensión de la declaración PRISMA para revisiones sistemáticas que incorporan metaanálisis en red: PRISMA-NMA. Medicina Clínica, 147(6), 262-266. https://doi.org/10.1016/j.medcli.2016.02.025

Hyysalo, S., Perikangas, S., Marttila, T., \& Auvinen, K. (2019). Intermediate Codesigning in Transi- 
tions Governance: Catalysing and Channelling Participant Action. The Design Journal, 22(6), 873-894. https://doi.org/10.1080/14606925.2019.1661557

Janssen, F. J. J. M., Könings, K. D., \& van Merriënboer, J. J. G. (2017). Participatory educational design: How to improve mutual learning and the quality and usability of the design? European Journal of Education, 52(3), 268-279. https://doi.org/10.1111/ejed.12229

Järvelä, S. (2015). El papel de la investigación sobre aprendizaje autorregulado en el desarrollo del aprendizaje colaborativo asistido por ordenador. Journal for the Study of Education and Development, Infancia y Aprendizaje, 38(2), 279-294. https://doi.org/10.1080/02103702.2015 .1016747

Kalantzis, M., \& Cope, B. (2010). The Teacher as Designer: Pedagogy in the New Media Age. ELearning and Digital Media, 7(3), 200-222. https://doi.org/10.2304/elea.2010.7.3.200

Kintu, M. J., Zhu, C., \& Kagambe, E. (2017). Blended learning effectiveness: the relationship between student characteristics, design features and outcomes. International Journal of Educational Technology in Higher Education, 14(1). https://doi.org/10.1186/s41239-017-0043-4

Kinzie, J., \& Kuh, G. (2017). Reframing Student Success in College: Advancing Know-What and Know-How. Change: The Magazine of Higher Learning, 49(3), 19-27. https://doi.org/10.1080/ 00091383.2017.1321429

Könings, K. D., Seidel, T., \& Merriënboer, J. J. G. V. (2014). Participatory design of learning environments: Integrating perspectives of students, teachers, and designers. Instructional Science, 42(1), 1-9. https://doi.org/10.1007/s11251-013-9305-2

Kuh, G. D. (2008). High-Impact Educational Practices. HIgh-Impact Educational Practices: What They Are, Who Has Access to Them, and Why They Matter. Assn of Amer Colleges.

Leinonen, T., \& Durall-Gazulla, E. (2014). Design thinking and collaborative learning. Comunicar, 21(42), 107-116. https://doi.org/10.3916/C42-2014-10

Littlejohn, A., \& Milligan, C. (2015). Designing MOOCs for professional learners: Tools and patterns to encourage self-regulated learning. ELearning Papers, 42, 38-45. Retrieved from https://doi.org/10.6084/M9.FIGSHARE.1428569

Magolda, M. B. B., \& Astin, A. W. (1993). What "Doesn't" Matter in College?What Matters in College: Four Critical Years Revisited. Educational Researcher, 22(8), 32-32. https://doi.org/ $10.2307 / 1176821$

Manso, M., \& Llamas, M. (2015). A Monitoring System to Ease Self-Regulated Learning Processes. Revista Iberoamericana de Tecnologias Del Aprendizaje, 10(2).

Marcelo, C., \& Rijo, D. (2019). Aprendizaje autorregulado de estudiantes universitarios: Los usos de las tecnologías digitales. Revista Caribeña de Investigación Educativa (RECIE), 3(1), 62-81. https://doi.org/10.32541/recie.2019.v3i1.pp62-81

Mccombs, B. L. (1989). Self-regulated learning and academic achievement: a phenomenological view. Nueva York: Springer-verlag. https://doi.org/10.1007/978-1-4612-3618-4_3

Mor, Y., \& Craft, B. (2012). Learning design: reflections upon the current landscape. Research in Learning Technology, 20, 85-94. https://doi.org/10.3402/rlt.v20i0.19196

Mor, Y., Ferguson, R., \& Wasson, B. (2015). Editorial: Learning design, teacher inquiry into student learning and learning analytics: A call for action. British Journal of Educational Technology, 46(2), 221-229. https://doi.org/10.1111/bjet.12273

Moreno, B., Muñoz, M., Cuellar, J., Domancic, S., \& Villanueva, J. (2018). Revisiones Sistemáticas: definición y nociones básicas. Revista clínica de periodoncia, implantología y rehabilitación oral, 11(3), 184-186. https://doi.org/10.4067/s0719-01072018000300184

OECD. (2019). OECD Skills Outlook 2019. Retrieved from http://dx.doi.org/10.1787/ 9789264276284-en https://doi.org/10.1787/df80bc12-en

Panadero, E., \& Alonso-Tapia, J. (2014). ¿Cómo autorregulan nuestros alumnos? Revisión del 
modelo cíclico de Zimmerman sobre autorregulación del aprendiza-je. Anales de Psicologia, 30(2). https://doi.org/10.6018/analesps.30.2.167221

Pastor, X., Lozano, R., \& Gros, B. (2017). El aprendizaje basado en la indagación y el codiseño experiencia aplicada. Experiencia aplicada en el Grado de Ingeniería Biomédica. Barcelona: Octaedro. Retrieved from https://url2.cl/J2Wc7

Penuel, W. R. (2019). Infrastructuring as a Practice of Design-Based Research for Supporting and Studying Equitable Implementation and Sustainability of Innovations. Journal of the Learning Sciences, 28(4-5), 659-677. https://doi.org/10.1080/10508406.2018.1552151

Pintrich, P. R. (2000). An Achievement Goal Theory Perspective on Issues in Motivation Terminology, Theory, and Research. Contemporary Educational Psychology, 25(1), 92-104. https://doi.org/10.1006/ceps.1999.1017

Roschelle, J., Penuel, W. R., \& Shechtman, N. (2006). Co-design of innovations with teachers: Definition and dynamics. Proceedings of the 7 th international conference on Learning sciences, 606-612.

Rotar, L. J., \& Kozar, M. (2017). The Use of the Kano Model to Enhance Customer Satisfaction. Organizacija, 50(4), 339-351. https://doi.org/10.1515/orga-2017-0025

Steffens, K., Bannan, B., Dalgarno, B., Bartolomé, A. R., Esteve-González, V., \& Cela-Ranilla, J. M. (2015). Avances en el aprendizaje enriquecido con la tecnología: Una evaluación enriquecida. RUSC Universities and Knowledge Society Journal, 12(2). https://doi.org/10.7238/rusc.v12i2 .2453

Trischler, J., Pervan, S. J., Kelly, S. J., \& Scott, D. R. (2018). The Value of Codesign: The Effect of Customer Involvement in Service Design Teams. Journal of Service Research, 21(1), 75-100.

Urrútia, G., \& Bonfill, X. (2010). Declaración PRISMA: una propuesta para mejorar la publicación de revisiones sistemáticas y metaanálisis. Medicina Clínica, 135(11), 507-511. https://doi.org/ 10.1016/j.medcli.2010.01.015

Wareing, L., Rodgers, P. A., \& Dunn, N. (2019). Co-designing Pathways to Opportunities for Young People in the North West of England. The Design Journal, 22, 863-883. https://doi.org/10 $.1080 / 14606925.2019 .1595405$

Weitze, C. L. (2015). Learning and Motivational Processes When Students Design CurriculumBased Digital Learning Games. Proceedings of The 9th European Conference on Games Based Learning : ECGBL 2015, 579-588.

Winne, P. H., \& Hadwin, A. F. (1998). Studying as self-regulated learning. In D. J. Hacker, J. Dunlosky, \& A. C. Graesser (Eds.), Metacognition in educational theory and practice. Lawrence Erlbaum Associates Publishers.

Winne, P. H., \& Hadwin, A. F. (2008). Studying as self-regulated learning. In D. J. Hacker, J. Dunlosky, \& A. C. Graesser (Eds.), The educational psychology series. Metacognition in educational theory and practice (pp. 277-304). Lawrence Erlbaum Associates.

Yu, E., \& Sangiorgi, D. (2018). Service Design as an Approach to Implement the Value Cocreation Perspective in New Service Development. Journal of Service Research, 21(1), 40-58. https:// doi.org/10.1177/1094670517709356

Zahedi, M., \& Heaton, L. (2017). A Model of Framing in Design Teams. Design And Technology Education. An International Journal, 22(2), 8-25.

Zhao, H. (2016). Factors Influencing Self-Regulation in E-learning 2.0: Confirmatory Factor Model. Canadian Journal of Learning and Technology, 42. Retrieved from https://doi.org/10.21432/ T2C33K

Zheng, L. (2015). A systematic literature review of design-based research from 2004 to 2013. Journal of Computers in Education, 2(4), 399-420. https://doi.org/10.1007/s40692-015-0036-Z

Zimmerman, B. J. (1989). A Social Cognitive View of Self-Regulated Academic Learning. Journal 
of Educational Psychology, 81(3), 329-339. https://doi.org/10.1037/0022-0663.81.3.329

Zimmerman, B. J. (2000). Attaining self-regulation: A social cognitive perspective. Handbook of SelfRegulation (pp. 13-39). Academic Press. https://doi.org/10.1016/B978-012109890-2/50031-7

Zimmerman, B. J. (2001). Theories of Self-Regulated Learning and Academic Achievement: An Overview and Analysis. Self-regulated Learning and Academic Achievement: Theoretical Perspectives. Lawrence Erlbaum Associates Publishers.

Zimmerman, B. J. (2008). Goal setting: A key proactive source of academic self-regulation. In D. H. Schunk \& B. J. Zimmerman (Eds.), Motivation and self-regulated learning. Theory, research and applications (pp. 267-295). Lawrence Erlbaum Associates.

Zimmerman, B. J., \& Moylan, A. R. (2009). Self-Regulation: Where Metacognition and Motivation Intersect. In D. J. Hacker, J. Dunlosky, \& A. C. Graesser (Eds.), Handbook of Metacognition in Education. Routledge. 